\title{
Penentuan Diagnostik Lymphadenopathy Colli Dengan Metode Biopsi pada Penderita HIV-TB Di Rumah Sakit Penyakit Infeksi Prof. Dr. Sulianti Saroso
}

\author{
Ida Bagus Sila Wiweka, Adria Rusli, Titi Sundari, Stevanus, Marti Kusumaningsih, \\ Sardikin Giriputro, Faisal Rizal Matondang, Ervan Budiman
}

Rumah Sakit Penyakit Infeksi Prof. Dr. Sulianti Saroso

\begin{abstract}
Abstrak. Mycobaterium tuberculosis (M.tuberculosis) telah menginfeksi sepertiga penduduk dunia. Salah satu manifestasi klinis yang terinfeksi M.tuberculosis adalah pembesaran kelenjar getah bening pada regio colli, axilla, inguinal, abdominal yang sering di sebut tuberkulosis kelenjar. Tuberkulosis kelenjar masih sering menimbulkan permasalahan baik dari segi diagnostik, pengobatan dan pemantauan hasil pengobatannya teristimewa di daerah endemis TB, ditambah lagi gejala tuberkulosis pada penderita HIV sering tidak jelas manifestasi yang sering timbul adalah pembesaran kelenjar getah bening.

Telah dilakukan penelitian pada 11 pasien HIV dengan pembesaran kelenjar getah bening leher yang diduga karena infeksi M.tb serta bersedia secara tertulis mengikuti penelitian ini. Pada semua subjek dilakukan biopsi jarum halus dan biopsi dengan pembedahan. Hasil biopsi tersebut dilakukan pemeriksaan pewarnaan langsung BTA; sitologi dan PCR. Hasil yang didapat adalah preparat BTA langsung dari BJH 36,4\%; Sitologi dari BJH positif tuberkulosis 36,4\%; PCR tuberkulosis positif 45,5\%; Hasil pemeriksaan Patologi Anatomi (PA) yang positif tuberkulosis adalah $72,7 \%$.

Berdasarkan penelitian perbandingan pemeriksaan Mycobaterium tuberculosis pada pembesaran KGB pada pasien HIV dianjurkan melakukan pemeriksaan PA dari bahan spesimen ekstirpasi dari kelenjar getah bening leher, pertimbangankan PCR tuberkulosis yang non invasif.
\end{abstract}

Kata Kunci : Kelenjar getah bening, PCR tuberkulosis, Patologi Anatomi.

Koresponden : Adria Rusli, RSPI Prof. Dr. Sulianti Saroso, Jl. Baru Sunter Permai, PapanggoTanjung Priok, Jakarta Utara, Telp:(021)6506559 ext.6001

\section{PENDAHULUAN}

Tuberkulosis (TB) merupakan masalah kesehatan dunia., ${ }^{1,2}$ Sekitar sepertiga penduduk dunia telah terinfeksi tuberkulosis dan sebagian besar (95\%) terdapat di negara berkembang.Pada tahun 2003 di seluruh dunia diperkirakan terdapat 8,8 juta kasus baru TB dengan 3,9 juta diantaranya berpotensi menularkan penyakit. $^{2}$ Indonesia menempati peringkat ketiga sebagai negara dengan insiden TB terbanyak menurut laporan WHO. ${ }^{3}$ Pada tahun 2004 , diperkirakan setiap tahun terdapat 539.000 kasus baru TB dan 101.000 kematian akibat TB. Insiden TB di Indonesia diperkirakan sekitar 234 per
100.000 orang dengan yang terus meningkat. $^{3}$ namun data terakhir menunjukan bahwa indonesia menempati posisi no 5 sebagai negara terbanyak penderita tb. ${ }^{4}$

Insidens penyakit TB akan mengalami peningkatan dengan masuknya HIV/AIDS. Kombinasi TB dengan HIV/AIDS sangat berbahaya dan mematikan. Menurut WHO, infeksi HIV terbukti merupakan faktor yang memudahkan terjadinya TB pada orang yang terinfeksi M.tuberculosis, meningkatkan risiko perubahan TB laten menjadi TB aktif dan kekambuhan TB, menyulitkan diagnosis TB dan memperburuk stigma. TB juga menjadi penyebab morbiditas dan mortalitas utama pada ODHA karena TB memperburuk status imunosupresi mereka. Koinfeksi HIV-TB akan menyulitkan penatalaksanaan TB karena menyebabkan gambaran klinis yang atipi, menurunkan sensitivitas pemeriksaan dahak, meningkatkan frekuensi alergi 
obat, meningkatkan resistensi Obat AntiTuberkulosis (OAT) dan meningkatkan angka kematian akibat infeksi lain selama pasien dalam pengobatan $\mathrm{TB}^{5}$.

Insidens penyakit TB akan mengalami peningkatan dengan masuknya HIV / AIDS. Kombinasi TB dengan HIV/AIDS sangat berbahaya dan mematikan., Menurut WHO, infeksi HIV terbukti merupakan faktor yang memudahkan terjadinya TB pada orang yang terinfeksi M. Tuberculosis, meningkatkan risiko perubahan TB laten menjadi TB aktif dan kekambuhan TB, menyulitkan diagnosis TB dan memperburuk stigma. TB juga menjadi penyebab morbiditas dan mortalitas utama pada ODHA karena TB memperburuk status imunosupresi mereka. Koinfeksi HIV-TB akan menyulitkan penatalaksanaan TB karena menyebabkan gambaran klinis yang atipi, menurunkan sensitivitas pemeriksaan dahak, meningkatkan frekuensi alergi obat, meningkatkan resistensi Obat AntiTuberkulosis (OAT) dan meningkatkan angka kematian akibat infeksi lain selama pasien dalam pengobatan TB. ${ }^{5}$

Pasien dengan HIV lebih cenderung memiliki manifestasi TB ekstrapulmonal dibandingkan pasien tanpa HIV. 40-80\% pasien TB dengan HIV meiliki manifestasi ekstrapulmonal, sedangkan pada pasien tanpa HIV hanya 10-20\%. Risiko terjadinya TB ekstrapulmonal meningkat dengan semakin rendahnya jumlah limfosit $T$ CD4. Manifestasi ekstrapulmonal yang umum terjadi ialah keterlibatan pleura dan kelenjar limfa, namun keterlibatan organ lainpun juga dapat terjadi seperti tulang dan sendi, jaringan lunak, system saraf pusat, dan perikardium. ${ }^{6}$ Pada infeksi lanjut juga sering ditemukan mikobakteremia (20$49 \%$ ) dibanding infeksi awal (0$7 \%$ ). ${ }^{6,8} \mathrm{Pada}$ tabel 1 tampak beberapa gejala klinis penderita HIV- TB.
Table 1. Clinical Manifestations of Tuberculosis in HIV infected patiens $(n=130)$

\begin{tabular}{lrr}
\hline \multicolumn{1}{c}{ Manifestations } & Number & $\begin{array}{c}\text { Percen- } \\
\text { tage }\end{array}$ \\
\hline Pulmonary & 104 & 80.00 \\
Tuberculosis & & \\
$\begin{array}{l}\text { Extra-pulmonary } \\
\text { tuberculosis }\end{array}$ & 50 & 38.46 \\
- Hilar/mediastinal & 14 & 10.77 \\
$\quad$ lymphadenopathy & & \\
- Extra-thoracic & 9 & 6.90 \\
$\quad$ lymphadenopathy & 18 & 13.85 \\
- Pleural effusion & 5 & 3.85 \\
- Miliary & 2 & 1.54 \\
$\quad$ tuberculosis & 1 & 0.77 \\
- Meningitis & 1 & 0.77 \\
- Ascites & & \\
- Pericardial & & \\
$\quad$ effusion & & \\
$\begin{array}{l}\text { Pulmonary } \\
\text { tuberculosis alone }\end{array}$ & 80 & 61.54 \\
$\begin{array}{l}\text { Extra-Pulmonary } \\
\text { tuberculosis alone }\end{array}$ & 26 & 20.00 \\
$\begin{array}{l}\text { Both pulmonary and } \\
\text { extra pulmonary } \\
\text { tuberculosis }\end{array}$ & 24 & 18.46 \\
\hline
\end{tabular}

Sumber : Zuber A, Mohd S. Manifestations of Tuberculosis in HIV Patients. JIACM 2005

Diagnosis pasti ditegakkan bila ditemukan basil Mycobacterium tuberculosis pada pemeriksaan sediaan langsung dan/atau kultur dahak. Pemeriksaan ini biasanya disebut pemeriksaan dahak BTA. Pemeriksaan sputum penting karena ditemukannya kuman bakteri tahan asam (BTA), diagnosis tuberkulosis sudah dapat dipastikan. Di samping itu pemeriksaan sputum juga dapat memberikan evaluasi terhadap pengobatan yang sudah diberikan. Dalam pemeriksaan sputum, pasien dianjurkan minum air sebanyak kurang lebih 2 liter dan diajarkan melakukan refleks batuk. Dapat juga dengan memberikan tambahan obat mukolitik ekspektoran, dapat juga dengan cara bronkoskopi. ${ }^{7}$ Namun pada penderita Limfadenitis TB hal ini sulit dilakukan karena biasanya tidak ada kelainan di organ paru jadi tidak didapatkan sputum. Untuk mendiagnosis TB kelenjar dibutuhkan pemeriksaan biopsi jarum halus atau biopsi eksisi, namun masalah yang timbul adalah angka kepositifannya yang rendah. 
Penelitian ini diharapkan memperoleh uji diagnosis pada TB kelenjar dengan membandingan uji BTA langsung, Biakan \& PCR TB.

\section{METODOLOGI}

Semua pasien HIV dewasa yang berobat di RSPI Prof dr. Sulianti Saroso mulai Januari 2011 sampai Desember 2011 yang terbukti dengan pemeriksaan rapid test dan Elisa yang mempunyai temuan klinis pembesaran kelenjar getah bening leher dan bersedia mengikuti penelitian ini ada 11 subjek. Subjek mengalami pemeriksaan biopsi jarum halus dan biopsi/ eksisi pada kelenjar getah bening yang sama. Setelah biopsi jarum halus dilakukan pemeriksaan langsung dengan metode pewarnaan ZeilNeilson, sitologi dan PCR tuberkulosis, sedangkan bahan dari biopsi /eksisi untuk pemeriksaan Patologi Anatomi.

\section{HASIL}

Dari 226 subjek penderita HIV didapatkan 122 penderita juga menderita TB dan hanya 15 penderita yang didiagnosis limfadenitis TB-HIV namun hanya 11 orang pasien dengan HIV positif dan pembesaran kelenjar getah bening leher yang bersedia mengikuti penelitian ini dengan serangkaian pemeriksaan sesuai prosedur penelitian dari data yang ada didapatkan karakteristik pasien seperti pada tabel 2 di bawah ini :

Tabel 2. Karakteristik pasien limfadenopati colli dan HIV berdasarkan umur, LED,SGOT,SGPT,CD4,Leukosit, Segmen dan Lymphosit.

\begin{tabular}{lcc}
\hline Karkateristik & Rerata & Kisaran \\
\hline Umur & 31,82 & $25-43$ \\
\hline LED & 56,27 & $15-94$ \\
\hline SGOT & 50,91 & $15-156$ \\
\hline SGPT & 53,55 & $12-234$ \\
\hline CD4 & 37,36 & $8-90$ \\
\hline Leukosit & 7,66 & $4-15(\mathrm{rb})$ \\
\hline Segmen & 76,73 & $62-90 \%$ \\
\hline Lymphosit & 17,55 & $8-30 \%$ \\
\hline
\end{tabular}

Tabel 3. Karakteristik pasien berdasarkan jenis kelamin, pekerjaan dan merokok.

\begin{tabular}{lcc}
\hline Karkateristik & $\mathrm{n}$ & $\%$ \\
\hline Jenis Kelamin & & \\
Laki-laki & 10 & 90.90 \\
Prempuan & 1 & 9.10 \\
\hline Pekerjaan & & \\
$\quad$ Swasta & 8 & 72.73 \\
lainya & 3 & 27.27 \\
\hline Merokok & & \\
Ya & 10 & 90.90 \\
tidak & 1 & 9.10 \\
\hline
\end{tabular}

Keluhan utama pada pasien terbanyak adalah batuk $(63,6 \%)$ seperti yang tampak pada tabel 4 di bawah ini:

Tabel 4. Keluhan utama pasien limfadenopati colli dan HIV

\begin{tabular}{lcc} 
Keluhan Utama & $\mathrm{n}$ & $\%$ \\
\hline BAB cair & & \\
Ya & 1 & 9.10 \\
Tidak & 10 & 90.90 \\
\hline Batuk & & \\
Ya & 7 & 63.63 \\
tidak & 4 & 36.36 \\
\hline Berat badan turun & & \\
Ya & 3 & 27.27 \\
Tidak & 8 & 72.73 \\
\hline
\end{tabular}

Gambaran radiologi yang terbanyak pada kasus yang di dapatkan adalah normal yaitu $6(54,5 \%)$ seperti tampak pada tabel 5 di bawah ini.

Tabel 5. Gambaran radiologi pasien limfadenopati colli dan HIV

\begin{tabular}{lcc}
\hline Toraks foto & $\mathrm{n}$ & $\%$ \\
\hline Bronkitis & 3 & 27,27 \\
\hline Normal & 6 & 54,55 \\
\hline TB parahiler & 2 & 18,18 \\
\hline
\end{tabular}

Pemeriksaan BTA untuk pada penelitian ini didapatkan terbesar adalah Biopsi kelenjar yaitu 72,7\% (8/11) seperti tampak pada tabel 6 dibawah ini: 
Tabel 6. Hasil biopsi pada pemeriksaan pasien limfadenopati colli dan HIV

\begin{tabular}{llc}
\hline Pemeriksaan & $\mathrm{n}$ & $\%$ \\
\hline $\begin{array}{l}\text { BJH untuk smear } \\
\text { langsung (ZN) }\end{array}$ & 4 & 36,4 \\
\hline BJH untuk Sitologi & 4 & 36,4 \\
\hline $\begin{array}{l}\text { BJH untuk PCR } \\
\text { Biopsi KGB untuk } \\
\text { PA }\end{array}$ & 5 & 45,5 \\
\hline
\end{tabular}

\section{PEMBAHASAN}

Pada penelitian ini didapatkan hasil, penderita Limfadenitsi TB-HIV paling banyak diderita oleh laki laki yaitu sebanyak $90,9 \%$, hal ini sesuai dengan penelitian terdahulu dan angka laporan kesakitan RSPI SS yang menyatakan lakilaki lebih banyak menderita TB-HIV. Hal ini diduga karena faktor risiko terjadinya HIV paling banyak adalah penggunaan narkoba suntik yang paling banyak melakukannya adalah laki laki, sedangkan untuk transmisi seksual kemungkinan karena laki laki lebih mudah mendapat akses pengobatan. ${ }^{9}$

Untuk data gejala klinis didapatkan data, batuk merupakan gejala terbanyak yaitu sekitar $63,6 \%$, hal ini sejalan karena subjek penelitian adalah penderita TB-HIV dan gejala batuk merupakan gejala yang paling banyak didapatkan. Untuk data gambaran radiologi didapatkan hampir sebagian besar normal, yaitu sekitar $54,5 \%$. Hal ini sesuai dengan teori atau hasil penelitian terdahulu yang menyatakan bahwa jika status imunitas penderita HIV berat maka gambaran radiologinya akan normal karena TB nya bermanisfestasi di ekstra-paru. Pada Penelitian didapatkan status imunitas HIV nya rendah terbukti dengan angka CD 4 yang rendah dibawah $200 / \mathrm{ul}$ dengan rerata sebesar $37,36 / \mathrm{ul}$.
Hasil pemeriksaan biopsi kelenjar getah bening didapatkan bahwa biopsi eksisi mempunyai angka kepositipannya yang paling besar sekitar $72,7 \%$. Hal ini menunjang teori atau penelitian sebelumnya yang menyatakan bahwa biopsi eksisi merupakan baku emas diagnostik limfadenitis TB. Ini disebabkan karena hasil sediaan biopsi eksisi adalah histopatologi yang relatif lebih besar dibandingkan dengan biopsi jarum halus yang merupakan sediaan sitologi. Namun karena tindakan biopsi eksisi lebih besar risikonya (traumatik lebih besar) dan membutuhkan biaya yang besar maka kita perlu mempunyai alternatif diagnosis lain yang lebih tidak traumatik dan tidak terlalu mahal. Dari penelitian ini didapatkan pemeriksaan PCR untuk hasil biopsi jarum halus mendapatkan kepositipannya sebesar $45,5 \%$.

\section{KESIMPULAN}

Berdasarkan hasil pemeriksaan biopsi kelenjar getah bening leher ada pasien HIV positif didapatkan yang terbaik adalah biopsi eksisi, mengingat tindakan ini memakai metode pembedahan maka dapat dipertimbangkan pemeriksaan PCR untuk tuberkulosis bagi pasien yang tidak berkenan dilakukan pembedahan.

\section{DAFTAR PUSTAKA}

1. Depkes RI. Pedoman Nasional Penanggulangan Tuberkulosis. Jakarta, 2007; 3-4.11.

2. Zuber A, Mohd S. Manifestations of Tuberculosis in HIV Patients. JIACM 2005; 6(4):302-5

3. Swaminathan S. Clinical presentation and treatment of HIV-TB. Ind J Tub 2002; 49:11-6.

4. Sharma SK, Mohan A, Kadhiravan T. HIV-TB co-infection: epidemiology, diagnosis\& management. Indian $\mathrm{J}$ Med Res 2005;121:550-67. 
5. Hudoyo A. Diagnosis TB-Paru Pada Pasien dengan HIV/AIDS. Jurnal Tuberkulosis Indonesia. 2008;4(2).

6. Departemen Kesehatan Republik Indonesia Direktorat Jenderal Pengendalian Penyakit dan Penyehatan Lingkungan. Pedoman Nasional : Panduan Tatalaksana Klinis Infeksi HIV pada orang Dewasa dan Remaja. Edisi ke-2. Jakarta. 2007.

7. Getahun H, Gunneberg C, Granich R, Nunn P. HIV Infection-Associated Tuberculosis: The Epidemiology and the Response. Clin Infect Dis. (2010) 50 (Supplement 3): S201-7.

8. Barnes PF, Lakey DL, Burman WJ. Tuberculosis in patients with HIV infection. Infectious Disease Clinics of North America 2002;1:16.

9. Laporan tahunan PRPI Prof $d r$ Sulianti Saroso;2013. 